\title{
IMPROVING THE QALITY OF PETROLEUM CRUDE OILS BY DEASPHALTING
}

\section{Shazly M. Salem, Galal M. Abdelaleem, Nadia A. Elsayed and Walaa Osman Saad}

Suez Canal University, Faculty of Petroleum \& Mining Engineering, Petroleum Refining and Petrochemical Engineering Department, Suez, Egypt

\section{(Received April 11, 2011 Accepted May 4, 2011)}

The heavy crude oils usually contain considrable amounts of asphaltenes. The high asphaltene contents in the crude oils would decrese the efficiency of the refining processes. Moreever, the high distribution of hetero-atoms (e.g. sulfur and nitrogen) in the asphaltene causes some problems such as pollution, corrosion and catalyst poisining. The main object of this contribution is to investigate the effect of the deasphalting process of crude oils in the sake of improving its properties and consequently increasing the efficiency of the refining processes.

Solvent extraction experiments using $n$-heptane as a solvent were conducted on three types of Egyptian heavy crude oils (Asran, Land Balayim and Geisum), these tests were also performed on three blends from these three crudes with different proportions.

The experimental results illustrate that deasphalting process leads to improve some key properties of crudes such as API gravity, viscosity, pour point, total sulfur content, and carbon residue.

\section{INTRODUCTION}

The world's supply of light sweet crudes has greatly diminished in recent years and the progressive depletion and rising cost of high quality crudes has created a need for away to inexpensively convert heavy crudes to pipelineable synthetic crudes[1].

The total world oil reserves are estimated to be $30 \%$ conventional oil, $15 \%$ heavy oil, $25 \%$ extra heavy oil, and $30 \%$ oil sands bitumen[2]. Within the next fifteen years, worldwide production of conventional crude oil is projected to peak and decline irreversibly reason why it will be necessary in this decade and the future ones to happen to use the non conventional production where heavy oil plays an important role to minimize the energy crisis. When petroleum sources are expanded to include heavy hydrocarbons, which include both heavy crude oil and natural bitumen, the outlook for domestic oil supplies is much improved. Worldwide deposits of heavy hydrocarbons are estimated to total almost 5.5 trillion barrels, and four-fifth of these deposits are in the Western Hemisphere on the other hand conventional crude oil reserves are estimated to 1 trillion barrels, and three-fifth of these crudes in the Middle East, worldwide distribution of conventional crude oil and heavy hydrocarbons are showed in Table (1) [3,4]. 
The United Nations Institute for Training And Research (UNITAR) has defined heavy crudes as those having an API gravity of less than 20, suggesting a high content of polyneuclear compounds and a relatively low hydrogen content. In addition to a high specific gravity, heavy crudes in general have other properties in common, including a high content of metals, nitrogen, oxygen, sulfur compounds, and high carbon residue. The heavy crudes generally are not fluid at ambient temperatures and dont meet local specifications for pipelineability [1].

Table (1) : Worldwide distribution of conventional crude oil and heavy hydrocarbons [4].

\begin{tabular}{|l|c|c|}
\hline \multicolumn{1}{|c|}{ Country } & Conventional crude oil & Heavy hydrocarbon \\
\hline United States & $3 \%$ & $6 \%$ \\
\hline Canada & $1 \%$ & $45 \%$ \\
\hline Other Western Hemispher & $15 \%$ & $26 \%$ \\
\hline Middle East & $60 \%$ & $9 \%$ \\
\hline Rest of World & $21 \%$ & $14 \%$ \\
\hline
\end{tabular}

The asphaltene fraction of crude oil is a dark brown to black friable solid that has no definite melting point and usually foams and swells on heating to leave a carbonaceous residue. The asphaltenes are obtained from petroleum by the addition of a nonpolar solvent with a surface tension lower than that of 25 dyne $\mathrm{cm}^{-1}$ at $25^{\circ} \mathrm{C}$, such as low-boiling petroleum naphtha, petroleum ether, n-pentane, iso-pentane, nheptane, liquefied petroleum gases.[5] The use of $n$-heptane as the precipitating medium yields a product that is different from the n-pentane-insoluble material.

The molecular weight of asphaltenes can vary from 1000 to 100000 [6].

The elemental composition of asphaltenes show that the amount of carbon and hydrogen usually vary over a narrow range $\mathrm{H \backslash C}$ atomic ratio of $1.15 \pm 0.5 \%$, in contrast to the carbon and hydrogen contents of asphaltenes notable variations occur in the proportions of the heteroelements in particular in the proportions of oxygen and sulfur. Oxygen content vary from $0.3 \%$ to $4.9 \%$ and sulfur content vary from $0.3 \%$ to $10.3 \%$, on the other hand, the nitrogen content has somewhat lesser degree of variation $(0.6 \%$ to $3.3 \%$ at the extremes)[5].

The actual structure of the constituents of the asphaltene fraction has proved to be difficult. There are indications that asphaltenes consist of condensed aromatic nuclei that carry alkyl and alicyclic systems with heteroelements (i.e., nitrogen, oxygen, and sulfur) scattered throughout in various; including heterocyclic locations [7].

The upgrading options means of crude oil are typically designed to convert low value heavy oil into higher value synthetic crude. Such technology would augment the supply of available crude and would make it possible for refiners to blend such synthetic crude with a more conventional feed for catalytic cracking and hydrocracking [1].

An early reference to the use of sulfuric acid was made by Marersson and Eickmann in 1908 who first precipitate the asphaltenes from asphaltic materials by treatment with low-boiling naphtha, followed by fractionation of the naphtha-soluble material with concentrated sulfuric acid, the precipitate produced by the sulfuric acid treatment was actually material that had been converted to an asphaltene-type product 
by interaction of the asphaltic constituents with the sulfuric acid, application of this method has led because emulsion formation and hence to difficulties in the separation procedure, and it must also be remembered that the use of the strong grades of sulfuric acid can lead to sulfonation of the constituents in many instances, and regeneration of these constituents to their natural state may be difficult if not impossible[7].

Deasphalting of heavy asphaltic crudes before significant thermal treatment produces deasphalted whole crude with reduced asphalt content relative to the feed and heating the deasphalted crude to temperature in excess of $500^{\circ} \mathrm{F}$ in a downstream refinery processes. We can define deasphalting process as a liquid-liquid separation operation that extracts the last of the easily convertible hydrocarbons from heavy oil [6].

Most deasphalting process use light aliphatic hydrocarbon such as propane, butane, pentane, etc., to precipitate asphaltic components from the feed. The choice of hydrocarbon solvent depends on the desired quality and yield of the deasphalted oil.

The solubility of oil in solvent at fixed temperature increases as the concentration of heavier components in the solvent increase. The selectivity is the ability of solvent to separate paraffinic and sometimes resinous oils from the crude. Practically any conventional deasphalting equipment and process can be used, for example the "ROSE" or Residual Oil Supercritical Extraction process may be modified for use here; although those modification necessary to accommodate use of a whole crude as feed rather than a reside fraction as feed, must be made.

The deasphalted whole crude may contain some of the deasphalting solvents and will have a much reduced asphaltene and metal content. It may safely be subjected to conventional thermal processing andlor solvent recovery steps e.g., one or more stages of flash vaporization and distillation to recover solvent for reuse in deasphalting process, and separate the (DWC) Deasphalted Whole Crude into various hydrocarbon fractions.

The asphalt fraction may be subjected to conventional stages of flash vaporization to recover solvent for reuse in deasphalting process, the asphalt phase may be used as is (for making roads), mixed with water or other cutter stocks to make a low grade fuel oil or coked to make more distillable product[1].

\section{EXPERIMENTAL WORK AND RESULTS}

In this research work three types of Egyptian heavy crude oils and three blends consists of different percentages from these crude oils were experimentally examined by a solvent extraction method using n-heptane to separate asphaltene fraction. These crude oils were obtained from Asran, Land Balayim, and Geisum wells, Table (2) lists the main characteristics of these crudes, and Table (3) show the properties of nheptane.

In this work n-heptane is used as a solvent to separate asphaltenes from crude oil for these reasons:

1) Volatility constraints and consistency of the asphaltene fraction favor the use of n-heptane.

2) The hydrogen-to-carbon atomic ratio of n-heptane precipitate is lower than that of the n-pentane precipitate, this indicates a higher degree of aromaticity in nheptane precipitate. 
3) Nitrogen-to-carbon, oxygen-to-carbon, and sulfur-to-carbon rations are usually higher in the n-heptane precipitate, indicating higher proportions of the heteroelements in this material.[5]

4) Solvent recovery in this work between 55.5 to $77.3 \%$.

\section{PROCEDURE}

1. Before deasphalting process the physical properties of crude oils such as (density, sulfur content, viscosity, pour point ...) was determined according to the standard methods ASTM [8].

2. Simple solvent extraction process for crude oil using n-heptane as a solvent was performed using solvent to oil ratio $9: 1$ at $40{ }^{\circ} \mathrm{C}$ for $45 \mathrm{~min}$ and surged with a consistent speed by an electro magnatic stirrer.

3. The asphaltene was separated by filteration process.

4. Solvent recovery by distillation for reuse in deasphalting process.

5. The deasphalting process was evaluated by the determination of key properties of deasphalted oils such (density, sulfur content, viscosity, pour point ...) according to the standard methods ASTM [8].

Table (2) : The main characteristics of the crude oils used.

\begin{tabular}{|c|c|c|c|c|c|c|c|}
\hline Test & $\begin{array}{c}\text { Standard } \\
\text { test }\end{array}$ & Asran & $\begin{array}{c}\text { Land } \\
\text { Balayim }\end{array}$ & Geisum & $\begin{array}{c}\text { Blend } \\
1\end{array}$ & $\begin{array}{l}\text { Blend } \\
2\end{array}$ & $\begin{array}{c}\text { Blend } \\
3\end{array}$ \\
\hline $\begin{array}{c}\text { Specific gravity } \\
\text { at } 60 / 60^{\circ} \mathrm{F}\end{array}$ & $\begin{array}{l}\text { ASTM } \\
\text { D1298 }\end{array}$ & 0.9909 & 0.9445 & 0.9016 & 0.9745 & 0.9337 & 0.92305 \\
\hline API gravity & $\begin{array}{l}\text { ASTM } \\
\text { D287 }\end{array}$ & 11.3 & 18.314 & 25.44 & 13.7 & 20.035 & 21.796 \\
\hline $\begin{array}{l}\text { Asphaltene } \\
\text { content wt. } \%\end{array}$ & $\begin{array}{l}\text { ASTM } \\
\text { D4124 }\end{array}$ & 29 & 18.67 & 5.386 & 21.25 & 13.36 & 8.3 \\
\hline $\begin{array}{c}\text { Sulfur content } \\
\text { wt. } \% \\
\text { (X-ray) }^{*}\end{array}$ & $\begin{array}{l}\text { ASTM } \\
\text { D4294 }\end{array}$ & 5 & 3.299 & 2.288 & 3.593 & 3.031 & 2.863 \\
\hline Pour point $\left({ }^{\circ} \mathrm{F}\right)^{*}$ & $\begin{array}{l}\text { ASTM } \\
\text { D97 }\end{array}$ & 90 & 65 & 70 & 70 & 60 & 55 \\
\hline $\begin{array}{c}\text { Conradson } \\
\text { carbon residue } \\
\text { wt. } \%\end{array}$ & $\begin{array}{l}\text { ASTM } \\
\text { D189 }\end{array}$ & 8.72 & 11.49 & 7.34 & 9.5 & 8.21 & 7.55 \\
\hline $\begin{array}{c}\text { Kinamatic } \\
\text { viscosity(C.St.) } \\
\text { At } 40^{\circ} \mathrm{C}\end{array}$ & $\begin{array}{l}\text { ASTM } \\
\text { D445 }\end{array}$ & 5037 & 394.11 & 37.47 & 1642.5 & 109.2 & 87.225 \\
\hline
\end{tabular}

Blend $1=50 \%$ Asran $+50 \%$ Land Balayim

Blend2 $=75 \%$ Land Balayim $+25 \%$ Geisum

Blend $3=50 \%$ Land Balayim $+50 \%$ Geisum

* NASR Petroleum Company Laporatory . 
Table (3) : Properties of $\mathbf{n}$-heptane as solvent .

\begin{tabular}{|l|c|}
\hline Name & N-Heptan \\
\hline Critical temperature & $542.1^{\circ} \mathrm{K}$ \\
\hline Molecular weight & 100.21 \\
\hline Molecular formula & $\mathrm{CH} 3-(\mathrm{CH} 2) 5-\mathrm{CH} 3$ \\
\hline Viscosity of n-C7 at $0{ }^{\circ} \mathrm{C}$ & $0.524 \mathrm{C} . \mathrm{P}$. \\
\hline Boiling range & $55-85^{\circ} \mathrm{C}$ \\
\hline Weight. per ml at $20^{\circ} \mathrm{C}$ & About $0.682-0.684 \mathrm{gm}$ \\
\hline
\end{tabular}

\section{EXPERIMENTAL RESULTS \& DISCUSSION}

The results obtained are reported in Tables (4-8) and illustrated in Figures(1-10), from these results indicated that properties of crude oils studied are enhanced after deasphalting process which increase the refining efficiency such as API gravity increase, and viscosity, pour point, sulfur content,and carbon residue decrease.

- API of deasphalted oil becomes higher because asphaltene fraction which has the lower API is eliminated from crude oil.

- As asphaltene fraction contain high percentage of heteroatoms, metal, and condensed aromatic rings so the deasphalted oil has low content of sulfur, metal, and carbon residue.

- The asphaltene fraction has long saturated chains attached to condensed polynuclear aromatic rings which increase pour point of crude oil so pour point decrease after deasphalting process.

- As asphaltene fraction is the more viscous fraction of crude oil, the viscosity of deasphalted oil become lower.

Table (4): API for crude oils before and after deasphalting.

\begin{tabular}{|c|c|c|}
\hline \multicolumn{3}{|c|}{ kinamatic Viscosity at $\mathbf{4 0}^{\mathbf{}} \mathbf{c}$} \\
\hline Crude & Before Deasphalting & After Deasphalting \\
\hline Asran & 5037 & 700.75 \\
\hline Land Balayim & 394.11 & 21.34 \\
\hline Geisum & 37.47 & 18.05 \\
\hline Blend1 & 1642.5 & 30 \\
\hline Blend2 & 109.2 & 24.57 \\
\hline Blend3 & 87.225 & 39.7 \\
\hline
\end{tabular}

Table (5) : Kinamatic viscosity at 400C forcrude oils before and after deasphalting

\begin{tabular}{|c|c|c|}
\hline \multicolumn{3}{|c|}{ API } \\
\hline Crude & Before Deasphalting & After Deasphalting \\
\hline Asran & 11.3 & 16.5 \\
\hline Land Balayim & 18.314 & 29.77 \\
\hline Geisum & 25.44 & 33.8 \\
\hline Blend1 & 13.7 & 24.18 \\
\hline Blend2 & 20.035 & 29.58 \\
\hline Blend3 & 21.796 & 32.93 \\
\hline
\end{tabular}


Table (6) : Carbon residue for crude oils before and after deasphalting

\begin{tabular}{|c|c|c|}
\hline \multicolumn{3}{|c|}{ Conradson Carbon Residue wt\% } \\
\hline Crude & Before Deasphalting & After Deasphalting \\
\hline Asran & 8.72 & 8.25 \\
\hline Land Balayim & 11.49 & 6.21 \\
\hline Geisum & 7.34 & 3.703 \\
\hline Blend 1 & 9.5 & 5.24 \\
\hline Blend 2 & 8.21 & 5.44 \\
\hline Blend 3 & 7.55 & 5.37 \\
\hline
\end{tabular}

Table (7): Pour point for crude oils before and after deasphalting.

\begin{tabular}{|c|c|c|}
\hline \multicolumn{3}{|c|}{ Pour Point o F } \\
\hline Crude & Before Deasphalting & After Deasphalting \\
\hline Asran & 90 & 60 \\
\hline Land Balayim & 65 & 45 \\
\hline Geisum & 70 & 55 \\
\hline Blend1 & 70 & 30 \\
\hline Blend2 & 60 & 45 \\
\hline Blend3 & 55 & 45 \\
\hline
\end{tabular}

Table(8) : Sulfur content for crude oils before and after deasphalting.

\begin{tabular}{|c|c|c|}
\hline \multicolumn{3}{|c|}{ Sulfur Content wt\% } \\
\hline Crude & Before Deasphalting & After Deasphalting \\
\hline Asran & 5 & 4.6 \\
\hline Land Balayim & 3.299 & 2.5 \\
\hline Geisum & 2.288 & 1.9 \\
\hline Blend1 & 3.593 & 3.3 \\
\hline Blend2 & 3.031 & 2.49 \\
\hline Blend3 & 2.863 & 2.3 \\
\hline
\end{tabular}

\section{CONCLUSIONS}

- The high asphaltic crude oils have higher density, viscosity, and have large amount of sulfur, nitrogen , metal, and carbon residue contents .

- The deasphalted crude oil has lighter density (higher API) than the origin crude oil.

- The viscosity of deasphalted crude oils becomes lower.

- The pour point of crude oils decreased after deasphalting process.

- The deasphalting process reduced total sulfur content of crude oils.

- Conradson Carbon residue of crude oils reduced after deasphalting process. 


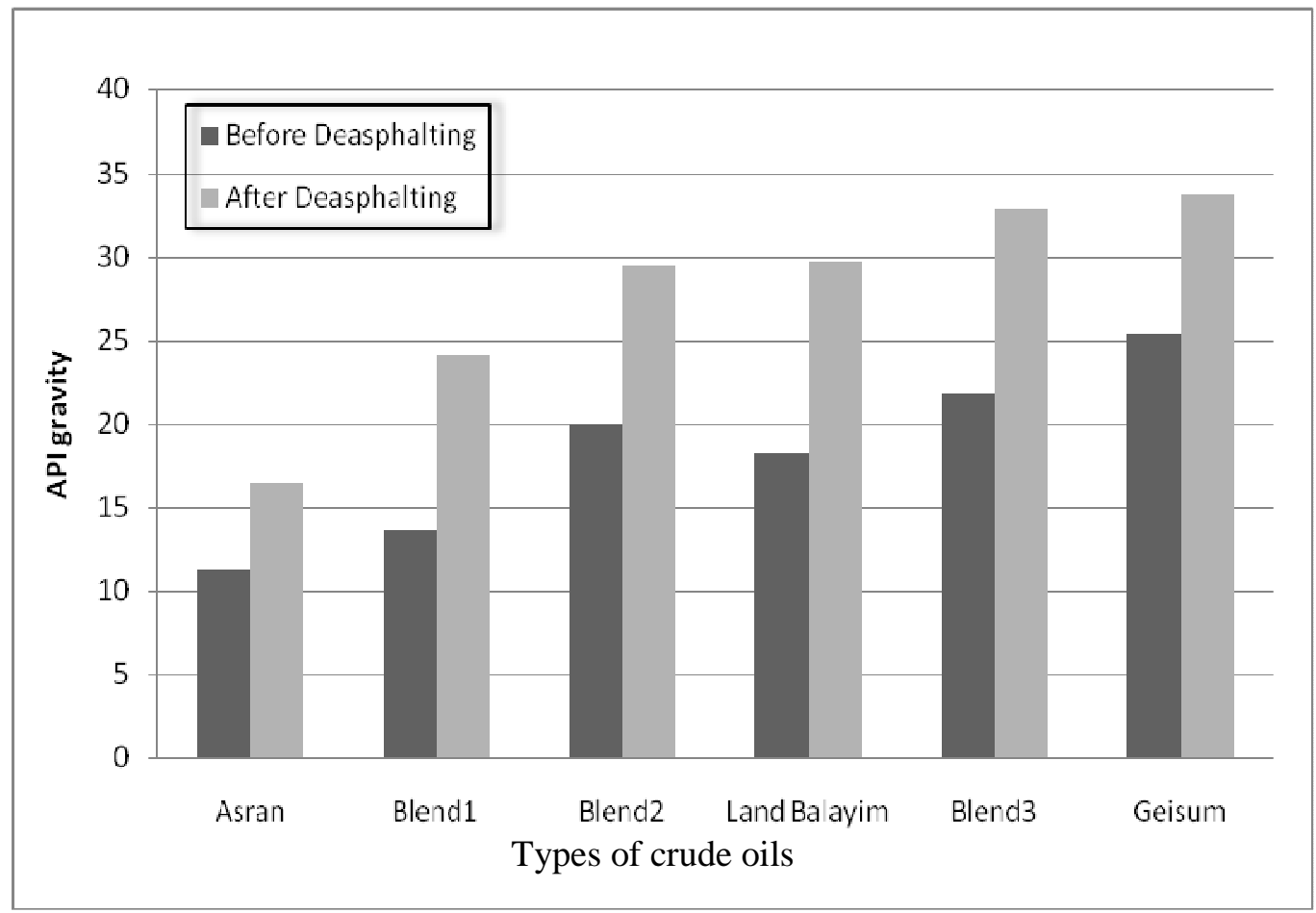

Figure (1) : Comparison between API gravity of crude oils before and after deasphalting.

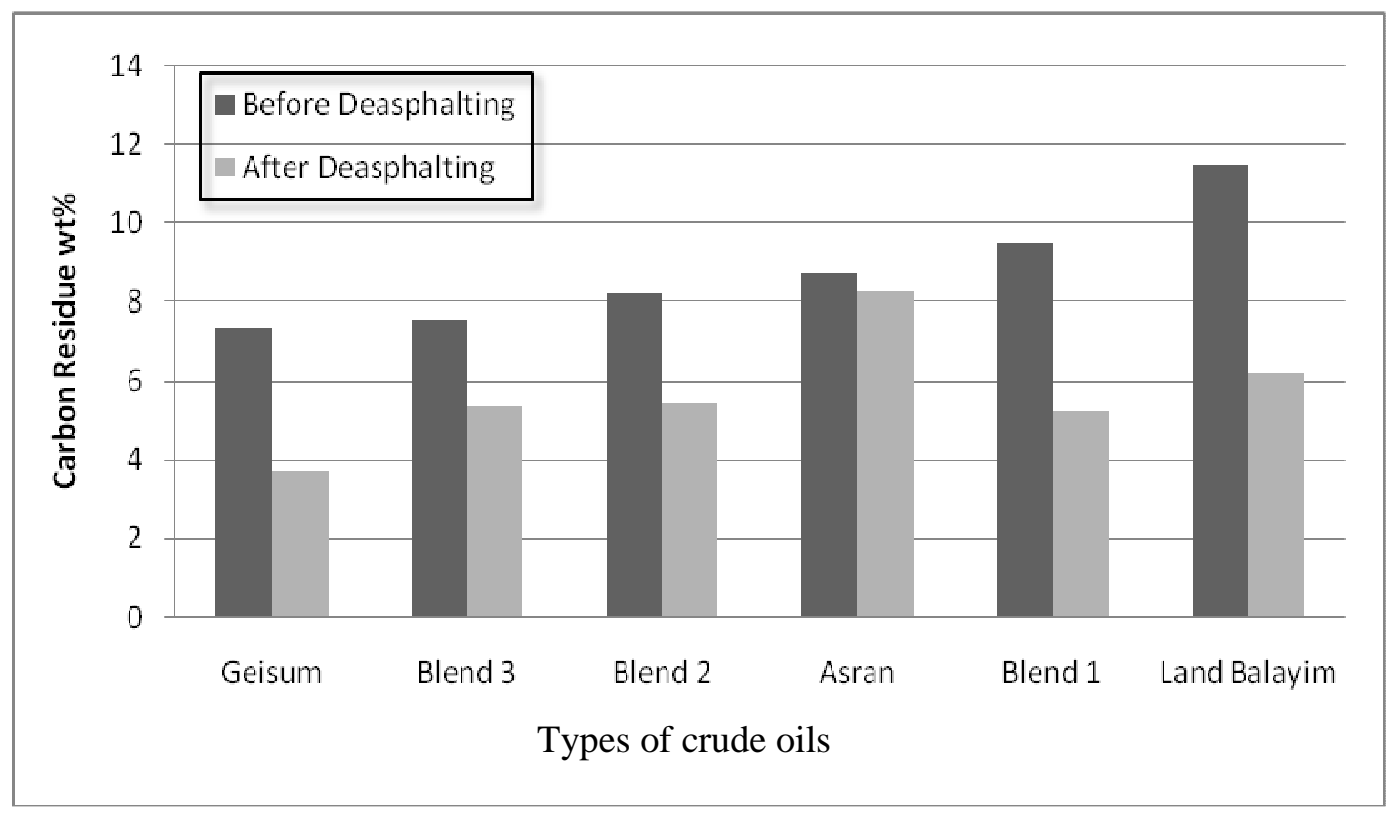

Figure (2):Comparison between carbon residue content of crude oils before and after deasphalting. 


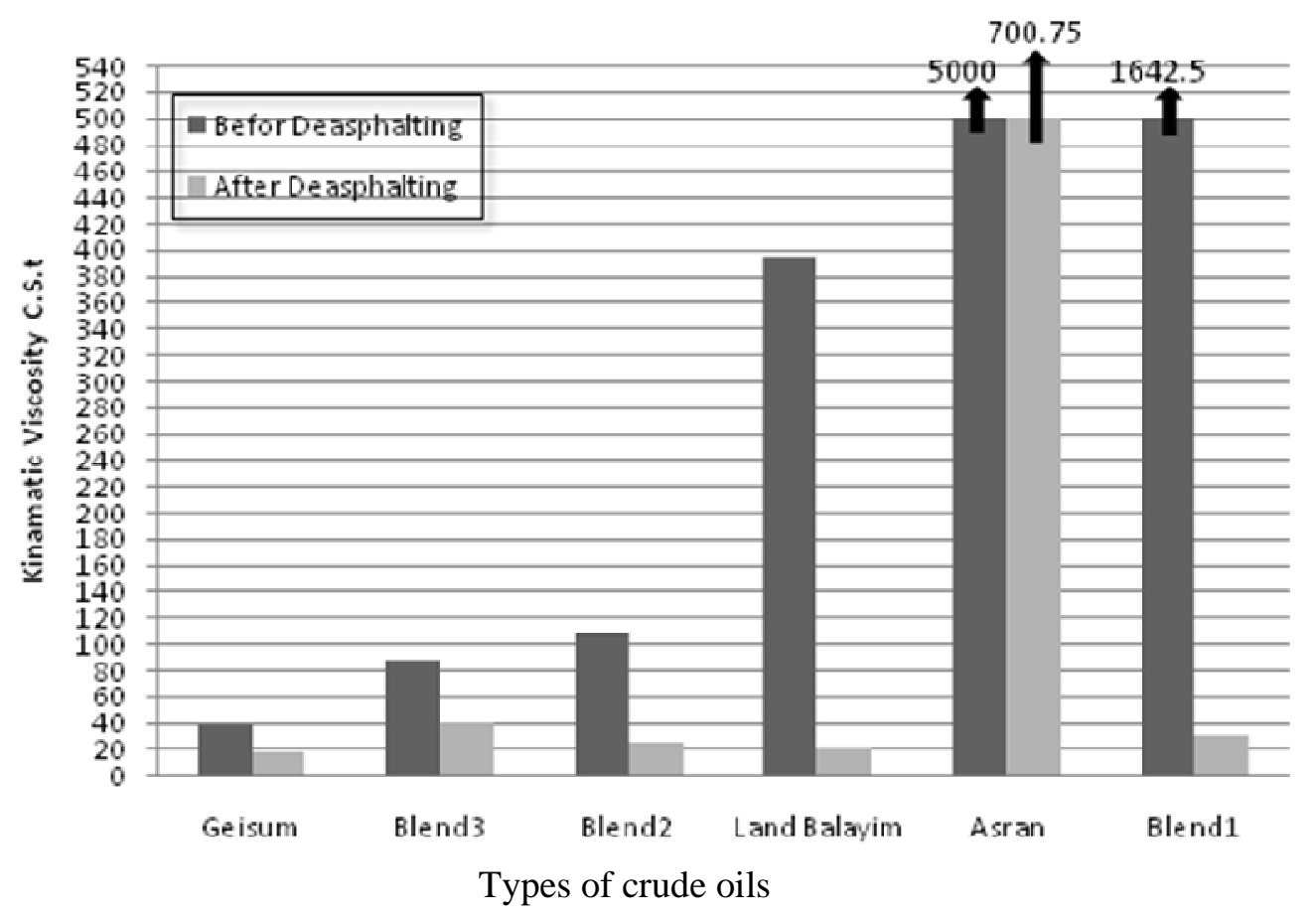

Figure (3): Comparison between viscosity of crude oils before and after deasphalting.

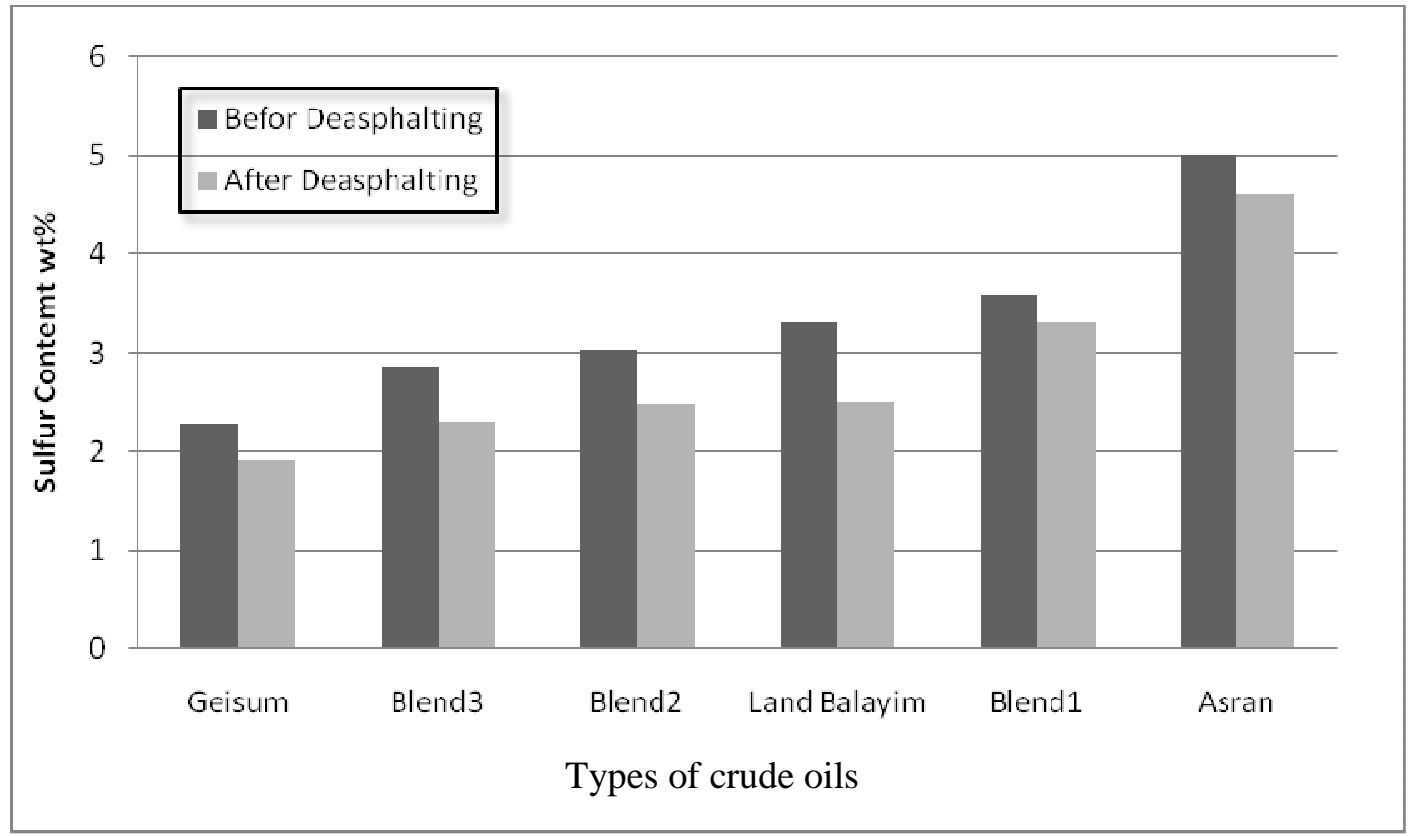

Figure (4) : Comparison between sulfur content of crude oils before and after deasphalting. 


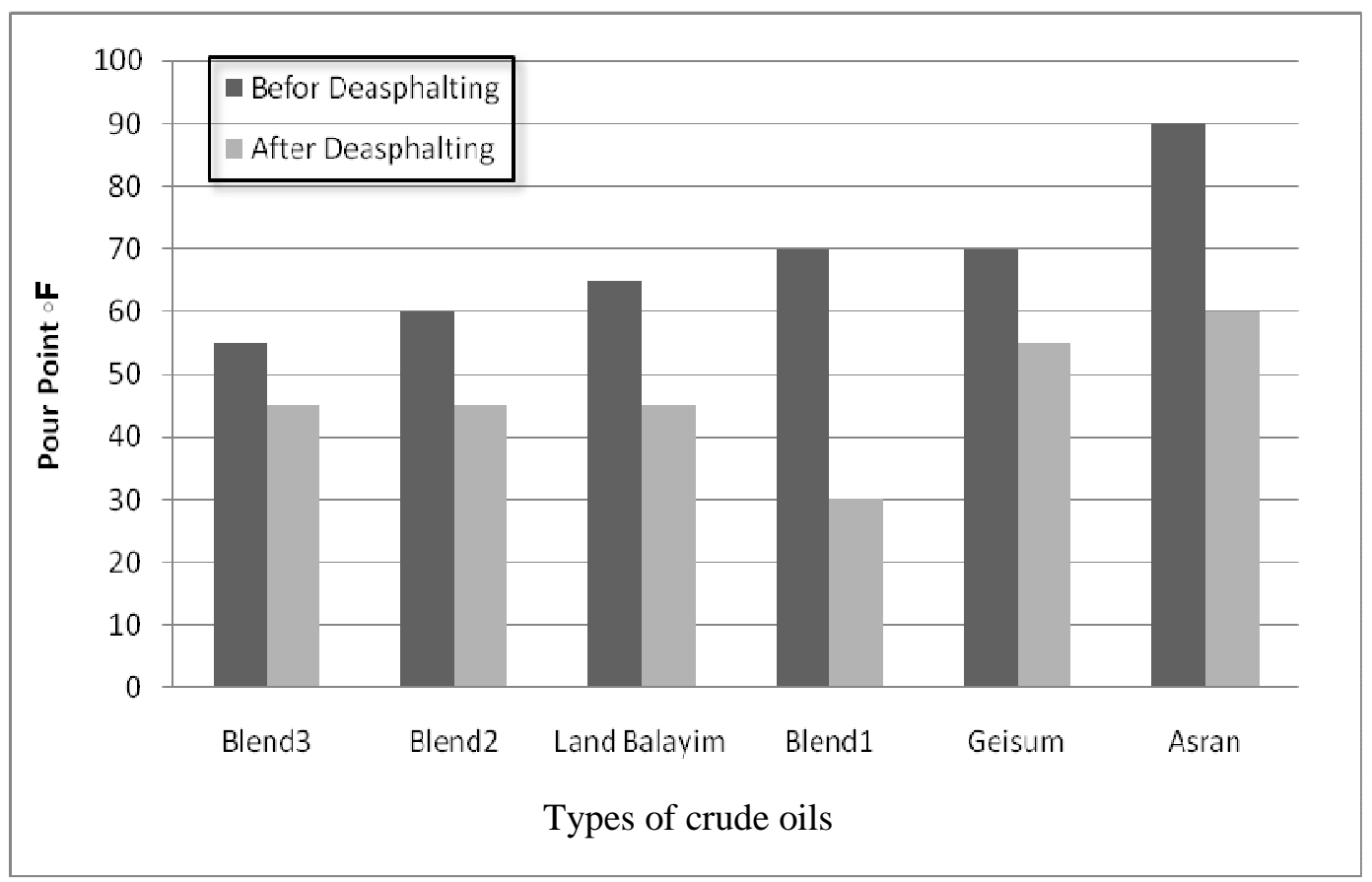

Figure (5) :Comparison between pour point of crude oils before and after deasphalting.

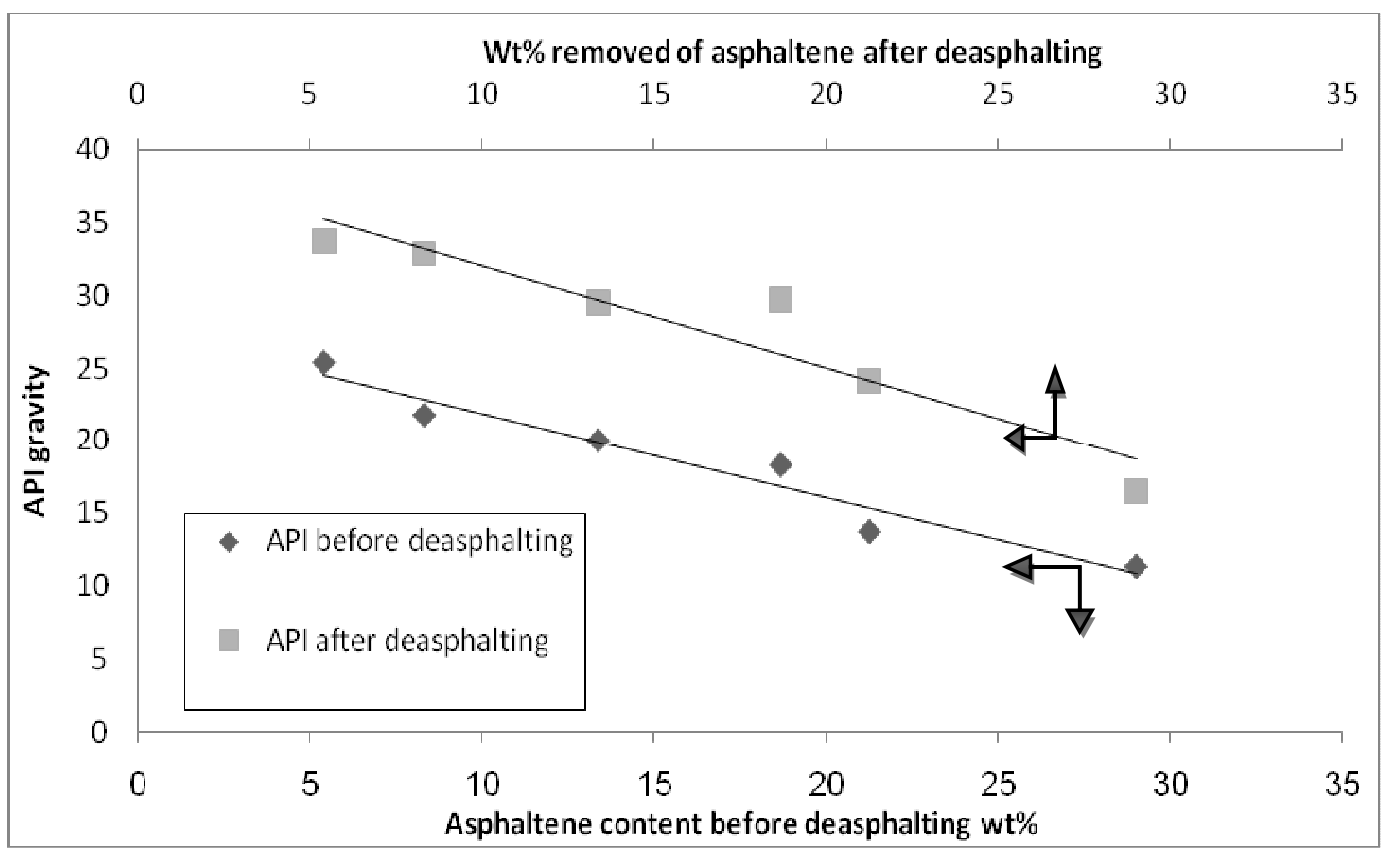

Figure (6):The effect of deasphalting process on API gravity for different types of crude oils. 


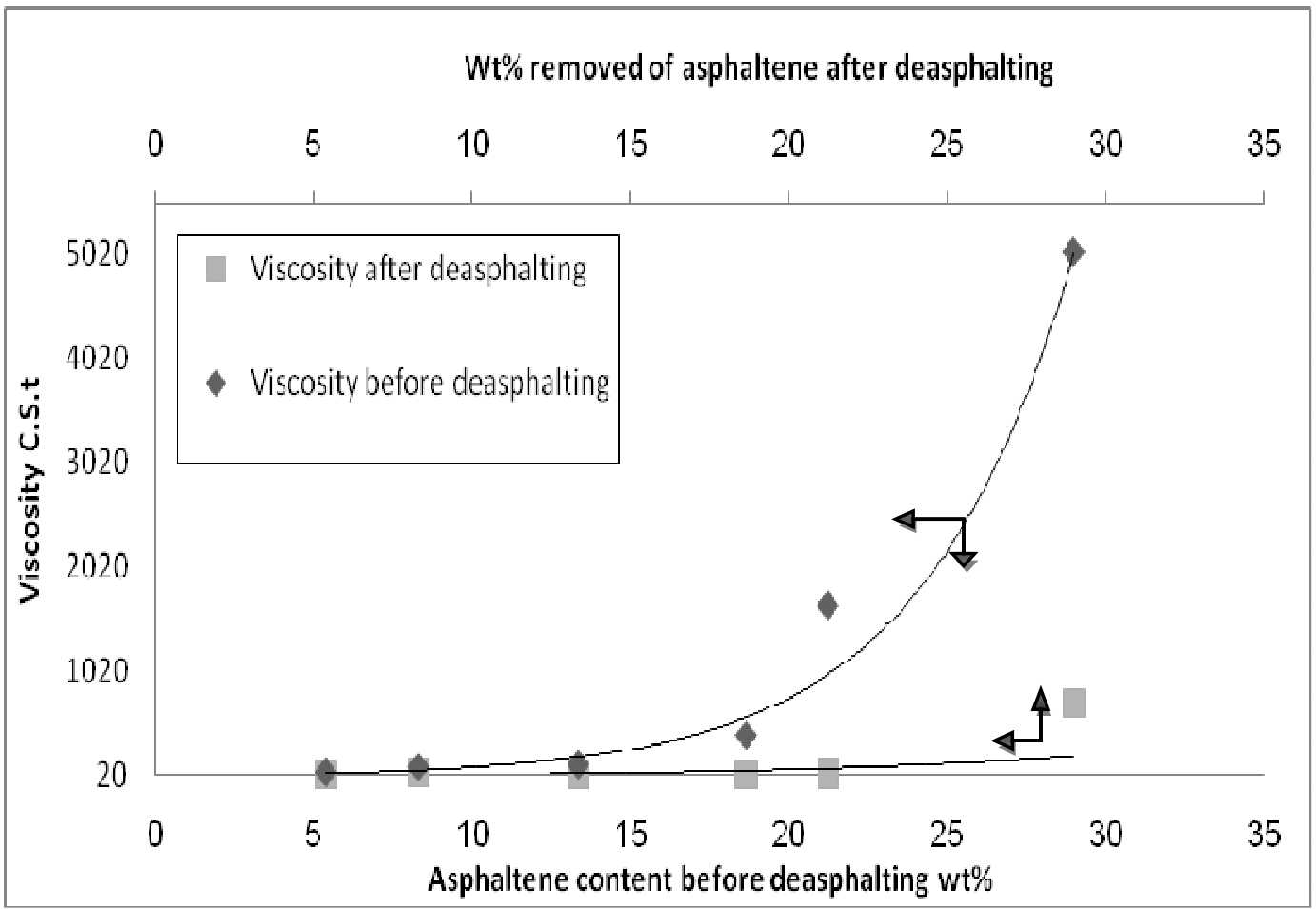

Figure (7) :The effect of deasphalting process on Viscosity for different types of crude oils.

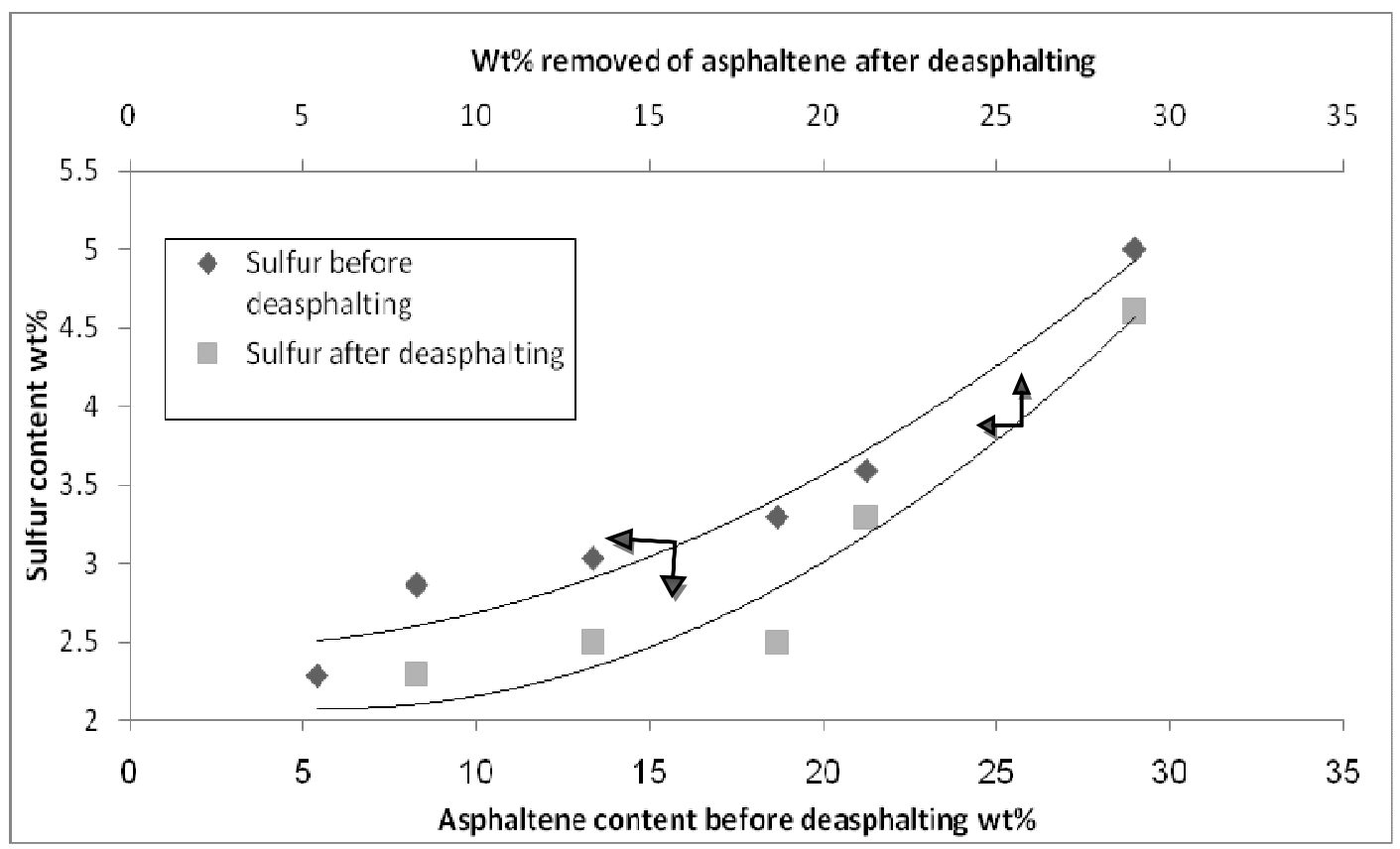

Figure (8) :The effect of deasphalting process on Sulfur content for different types of crude oils. 


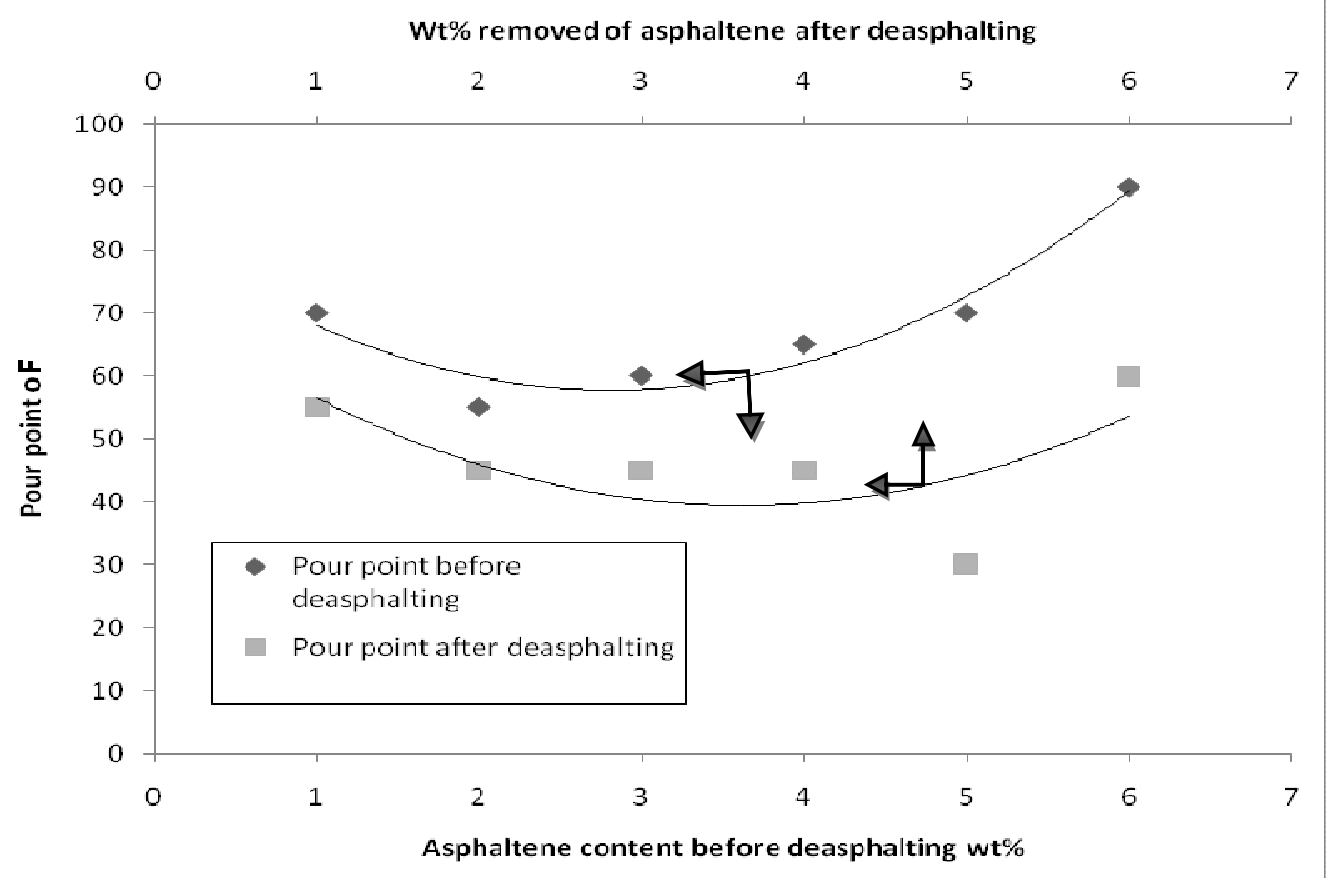

Figure (9): The effect of deasphalting process on pour point for different type of crude oils.

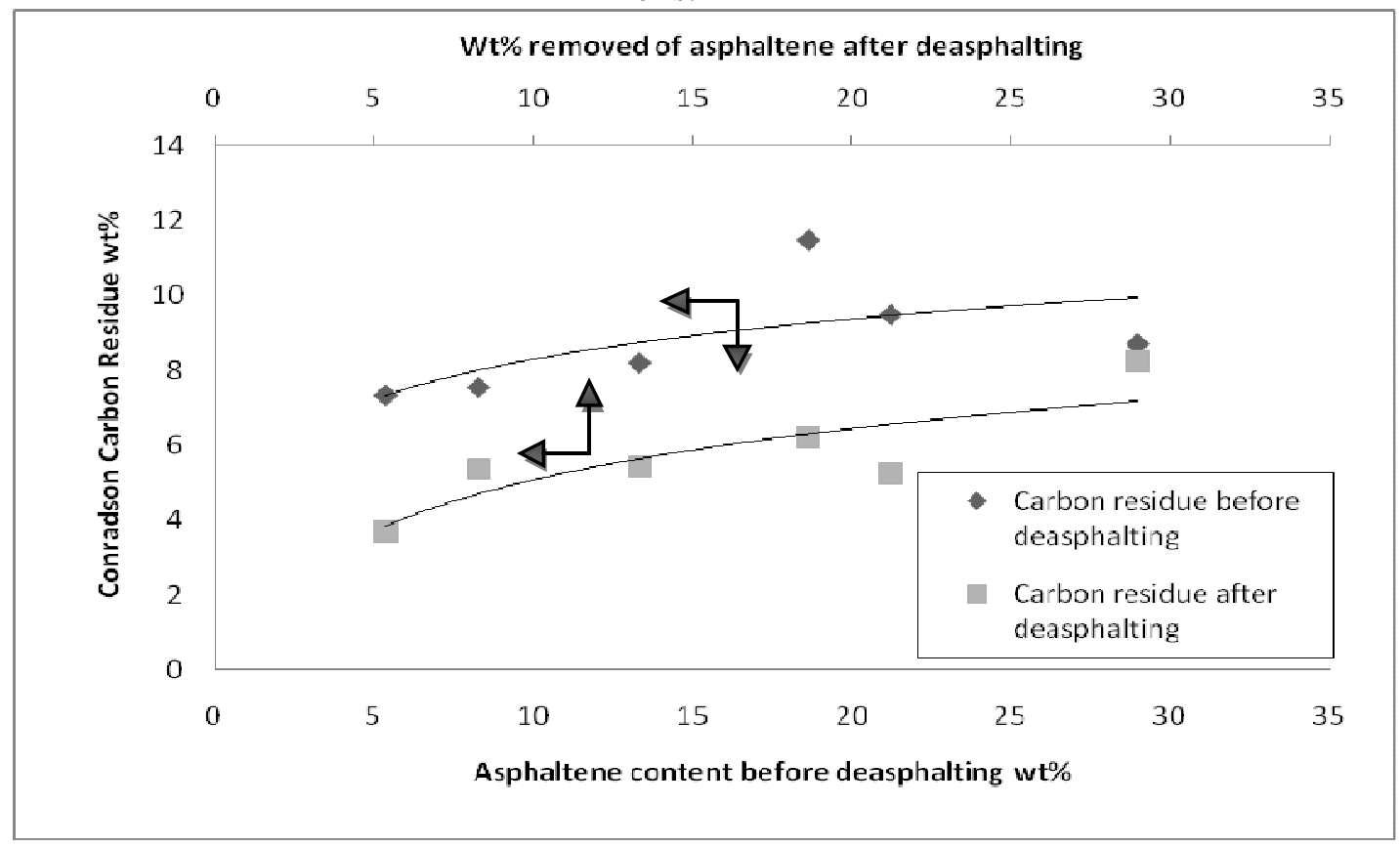

Figure (10): The effect of deasphalting process on carbon residue for different type of crude oils. 


\section{REFERENCES}

[1] Audeh, Costandi A. and Rankel, Lillian A. ,"Integrated process for whole crude deasphalting and asphaltene upgrading", U.S. patent No. 5192421, 3 sep., 1993.

[2] Nick A. Owen, Oliver R. Inderwildia and David A. King, "The status of conventional world oil reserves - Hype or cause for concern?" Energy policy vol 38 pp. 4743 - 4749, 2010.

[3] Eduardo Pachecol and Anand Subramanian, "Advanced Technology to Improve API Density of heavy Oils.", AAPG Hedberg Research Conference, Veracruz, Mexico, October 8-10, 2006.

[4] E. Hunter Herron, Ph.D., "Heavy oil: A Solution to Dwindling Domestic oil supplies", President, petroleum Equities Inc., September 2000.

[5] James G. Speight, "The chemistry and Technology of Petroleum.", $4^{\text {th }}$ edition Chapter (11) Taylor \& Francis Group,LLC, 2006.

[6] Jean-Pierre Wauquier, "Petroleum Refining" 1 Crude oil- Petroleum productsProcess flow sheets, Chapter (1), E'ditions Techip, Paris, 1994.

[7] James G. Speight "The chemistry and Technology of Petroleum." $3^{\text {rd }}$ edition, ,chapter(7 ) Marcel Dekker, Inc. United States of America, 1999.

[8] ASTM- standards, vol 05.01, American Society for Testing and Materials, philadelphia, 1984.

\section{تحسين جودة الخامات البترولية بواسطة فصل الأسفلت}

تحتوي الخامات البترولية النقيلة على كمية كبيرة من الأسفلتينات التي تعتبر مسئولة عن إرتفاع اللزوجة و الكتافة

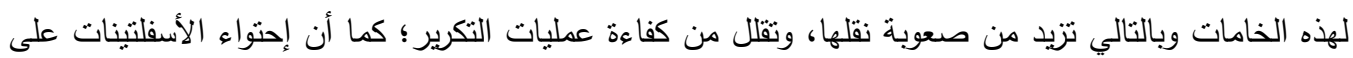
بعض العناصر الضارة مثل الكبريت والنيتروجين وبعض المعادن تتسبب في مشاكل التلوث وتسمم العوامل الحفازة

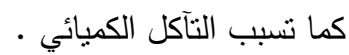

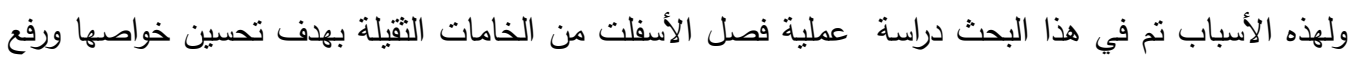

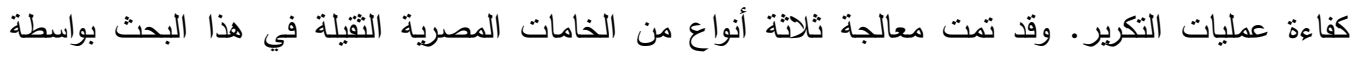

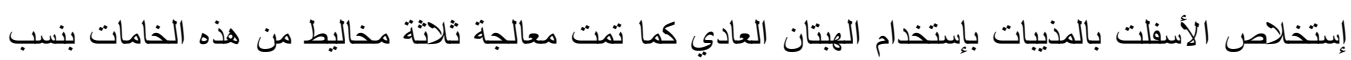

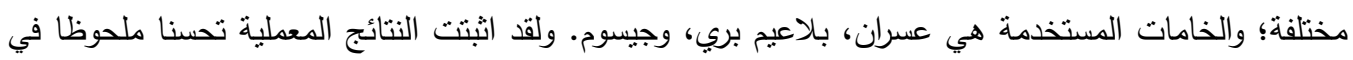

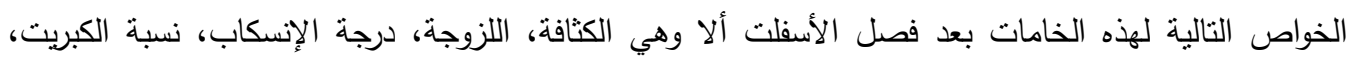
والمتبقي الكربوني. 